\title{
PENGELOLAAN ARSIP DINAMIS DALAM UPAYA PELAYANAN PRIMA BAGI TENAGA KEPENDIDIKAN PASCASARJANA UNNES
}

\author{
Agung Kuswantoro \\ Jurusan Pendidikan Ekonomi, Fakultas Ekonomi ,Universitas Negeri Semarang, \\ Perum Sekarwangi Gg 1 No. 9 Jalan Pete Selatan Sekaran Gunungpati Semarang \\ Penulis Korespondensi: agungbinmadik@ mail.unnes.ac.id
}

\begin{abstract}
Abstrak
Tujuan pengabdian kepada masyarakat ini adalah (1) untuk mengelola arsip dalam upaya pelayanan prima bagi tenaga kependidikan Pascasarjana UNNES. (2) memberikan kontribusi pengelolaan arsip dinamis bagi Pascasarjana UNNES yang baik dan benar. Tahapan pengabdian ini meliputi penyampaian materi, praktek arsip dinamis, dan mengevaluasi kegiatan. Realisasi pemecahan masalah dilakukan dengan cara pemberian teori dan praktik dengan dihadiri semua tenaga kependidikan PPs UNNES. Pengabdian ini merupakan dalam rangka pelayanan prima bagi tenaga kependidikan. Hasil dari pengabdian ini adalah peserta memahami teori yang disampaikan oleh tim pengabdi dan peserta mampu mempraktikkan pengelolaan arsip dinamis di unit kerjanya. Pengelolaan arsip dinamis dimulai dari penciptaan arsip. Simpulan dalam pengabdian ini adalah peserta memahami penataan arsip dinamis yang ada di PPS UNNES dan memberikan dampak dalam memberikan pelayanan prima bagi tenaga kependidikan PPS UNNES. Saran dalam pengabdian ini adalah peserta pelatihan harus terampil dalam penataan arsip mulai dari pemberkasan, pencatatan, penyimpanan, dan pengembalian arsip dengan mempraktekkan secara langsung di unit kerjanya. Selain itu, perlu didukung sarana dan prasarana dalam mendukung penataan arsip, serta pembiayaan program kearsipan yang minim.
\end{abstract}

Kata Kunci: Arsip Dinamis, Pelayanan Prima, dan PPs UNNES

\begin{abstract}
The aims of this society dedication are (1) to manage the archives in a bid to provide high quality service for educators (2) Contributes to the management of the record management for the good and true of Postgraduate in UNNES. The steps of this dedication are material distribution, record practices, and evaluation of program. This dedication is held in order to give an excellent service for the educators. The results are the participants understand about theory which is delivered by worshiper team and participants are able to practice in managing record in the workplace. The management of record archives start from creating of archives. This excogitation consists of production, acceptance, recording, and retention of archive. Moreover, suggestion of this dedication are the participants of training shoud be skilled to arrange record including filing, recording, saving, and returning of archive with directly practice in the workplace. In addition, it needs to supported by good facilities in order to bloster the management of archive, and archival program financing is minimal.
\end{abstract}

Keywords: record, excellent service, postrgaduate of UNNES

\section{PENDAhUlUAN}

Arsip mempunyai peran penting dalam kelangsungan hidup organisasi baik organisasi pemerintah maupun swasta. Manfaat arsip bagi suatu organisasi antara lain berisi informasi yang berguna dalam pengambilan keputusan dan juga dapat dijadikan sebagai alat bukti apabila terjadi masalah serta dapat dijadikan alat pertanggung jawaban menajemen. Selain itu dapat dijadikan alat transparansi birokrasi. Arsip dapat bermanfaat secara optimal bagi organisasi apabila dikelola dengan tertib dan teratur, namun sebaliknya apabila arsip dikelola dengan tidak tertib akan menimbulkan masalah bagi suatu organisasi. Menumpuknya arsip yang tidak ada gunanya serta sitem tata arsip yang tidak menentu akan mengakibatkan ruangan terasa sempit dan tidak nyaman sehingga dapat berpengaruh negatif terhadap kinerja pelaksanaan tugas dan fungsi suatu organisasi. Apabila suatu arsip sulit untuk ditemukan akan menjadi hambatan dalam proses pengambilan keputusan dan akan mempersulit proses hukum dan pertanggungjawaban.

Masalah kearsipan belum sepenuhnya menjadi perhatian baik oleh masyarakat umum, organisasi 
pemerintah maupun suatu organisasi swasta. Banyak orang yang masih belum mengetahui atau belum memahami arti penting dan manfaat arsip dalam kehidupan sehari-hari bagi pribadi maupun bagi organisasi, orang menganggap bahwa arsip relatif masih sangat rendah dan arsip selama ini masih dianggap rendahan.

Setiap kegiatan organisasi baik itu organisasi pemerintah maupun swasta tidak terlepas dari lingkup administrasi karena hal tersebut merupakan suatu kesatuan yang tidak dapat dipisahkan. Organisasi tanpa kegiatan administrasi maka organisasi tidak akan dapat tercapai visi dan misinya dengan efektif. Untuk mewujudkan tertib pengelolaan arsip ada beberapa aspek yang mesti ditangani secara serius, yaitu terdapatnya sistem pengelolaan kearsipan yang efektif, pelaksanaan sistem yang telah ditetapkan secara berdaya guna dan berhasil guna, serta evaluasi secara tajam dan terus menerus terhadap pelaksanaan sistem itu sendiri. Ketiga aspek ini dapat terlaksana apabila didukung oleh unsur-unsur sumber daya manusia yang diperlukan, anggaran dan sarana pendukung. Penciptaan arsip meliputi pembuatan, penerimaan, dan registrasi. Perhatikan gambar berikut:

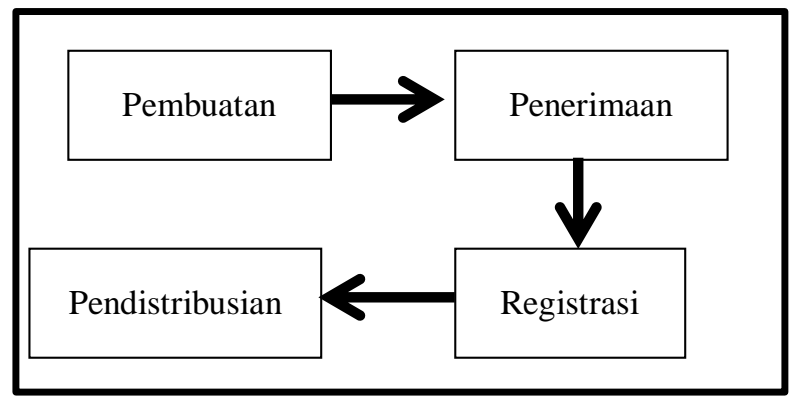

Gambar 1. Penciptaan Arsip

Sumber : Pedoman Kearsipan UNNES (2013)

Penciptaan Arsip meliputi pembuatan, penerimaan, registrasi, dan pendistribusian arsip. Pembuatan arsip adalah kegiatan merekam informasi dalam suatu media rekam tertentu untuk dikomunikasikan dalam rangka melaksanakan fungsi dan tugas perguruan tinggi dengan memperhatikan (1) arsip yang dibuat memiliki isi, struktur, dan konteks, (2) Pembuatan arsip yang dinilai sebagai arsip vital/statis dilaksanakan dengan media rekam dan peralatan berkualitas baik, (3) untuk memenuhi autentisitas dan reliabilitas arsip, serta pengelompokan arsip sebagai satu keutuhan informasi maka jadi dalam pembuatan arsip dilaksanakan berdasarkan tata naskah dinas, klasifikasi, serta klasifikasi keamanan dan akses arsip. (4) Pembuatan arsip dilaksanakan berdasarkan klasifikasi keamanan dan akses arsip untuk menentukan keterbukaan atau kerahasiaan arsip sesuai dengan peraturan perundang-undangan, dan (5) Pembuatan arsip harus didokumentasikan dengan cara registrasi yang dilakukan oleh arsiparis.

Penerimaan arsip adalah kegiatan yang berhubungan dengan pengaturan arsip yang berasal dari pihak luar (organisasi dan/atau individu). Dalam penerimaan arsip yang perlu diperhatikan yaitu (1) Arsip yang diterima dalam kondisi aman, tepat, lengkap, dan jelas terbaca (2) Arsip dianggap sah diterima setelah sampai pada petugas penerima arsip yang berwenang. (3) Arsip dalam bentuk faksimili dianggap sah diterima setelah tercetak oleh mesin faks penerima arsip. (4) Arsip dianggap sah diterima setelah sampai pada penerima yang berhak dan penerimaan arsip itu harus didokumentasikan dengan cara diregistrasi oleh unit yang mewadahi fungsi persuratan untuk kemudian ditindak lanjuti oleh unit pengolah. Pendokumentasian penerimaan arsip dilakukan oleh arsiparis untuk dipelihara, disimpan, dan digunakan.

Registrasi arsip adalah kegiatan pencatatan arsip yang dibuat atau diterima oleh Universitas Negeri Semarang ke dalam sistem kearsipan, dengan memperhatikan (1) Registrasi dilakukan secara lengkap dan konsisten, (2) Registrasi dilakukan dengan memberikan kode yang bertujuan untuk merekam informasi yang ringkas mengenai arsip. (3) Data registrasi tidak boleh diubah-ubah, namun apabila diperlukan perubahan karena terjadi kesalahan teknis, maka harus dilakukan pencatatan perubahan.

Registrasi arsip dilakukan dengan mencatat informasi arsip seuai dengan standar metadata kearsipan, dan sekurang-kurangnya meliputi nomor dan tanggal registrasi, nomor dan tanggal arsip, tanggal penerimaan dan pengiriman, instansi penerima dan pengirim, isi ringkas, dan kode klasifikasi.

Pendistribusian arsip adalah penyampaian arsip atau pengendalian pergerakan arsip dari satu unit kerja ke unit kerja lain di lingkungan Universitas Negeri Semarang, dengaan memperhatikan (1) Distribusi arsip dilakukan setelah arsip yang berkaitan dinyatakan lengkap. (2) Distribusi arsip dilakukan dengan cepat, tepat, lengkap dan aman. (3) Distribusi arsip disertai dengan pengendalian pergerakan arsip di lingkungan Universitas Negeri Semarang. Pendistribusian arsip dilakukan melalui prosedur yaitu penyampaian arsip ke unit kerja di lingkungan Universitas Negeri Semarang, pengendalian arsip, penyampaian arsip ke pimpinan, dan pengendalian terhadap pergerakan arsip di lingkungan perguruan tinggi.

Kendala-kendala dalam pengelolaan kearsipan PPs UNNES yaitu belum adanya SOP (Standard Operational Procedure) kearsipan yang dibuat oleh PPs UNNES sehingga dalam pelaksanaan mengenai kearsipan belum jelas, seperti cara penyimpanan, cara peminjaman, dan pengembalian arsip. Arsip masih dikelola dengan sederhana yaitu disimpan di map saja, tanpa ada pencatatan atau pola klasifikasi kearsipan sehingga saat mencari arsip membutuhkan waktu yang lama. Antara subunit satu dengan subunit lainnya dalam menata arsip ada perbedaaan, karena tidak adanya pedoman kearsipan di PPs UNNES.

Kendala lainnya adalah minimnya sumber daya kearsipan mulai dari sumber daya manusia (SDM), peralatan, dan keuangan. SDM kearsipan di PPs UNNES yang mengelola kearsipan di unit kerja dan subunit kerja berapa pada kantor Tata Usaha (TU) dan 
prodi-prodi. SDM tersebut sebagian besar, bukan berasal dari lulusan kearsipan atau pendidikan administrasi perkantoran, oleh karenanya pemahaman mengenai kearsipan sangat minim. Hal ini berdasarkan pada angket yang pengabdi buat bahwa hanya ada tiga pegawai (SDM) yang pernah belajar manajemen kearsipan. Mereka berasal dari lulusan pendidikan administrasi perkantoran UNNES.

Peralatan kearsipan yang ada berupa filing cabinet. Dalam dalam filing cabinet tidak adanya map gantung atau peralatan kearsipan lainnya, seperti guide. Arsip yang disimpan di PPs UNNES, prinsipnya masuk ke laci filing cabinet, tanpa ada petunjuk atau pemberian kode kearsipan. Peralatan yang ada berupa lemari yang arsip, namun tidak sesuai standar kearsipan. Adapun gambarnya sebagai berikut:

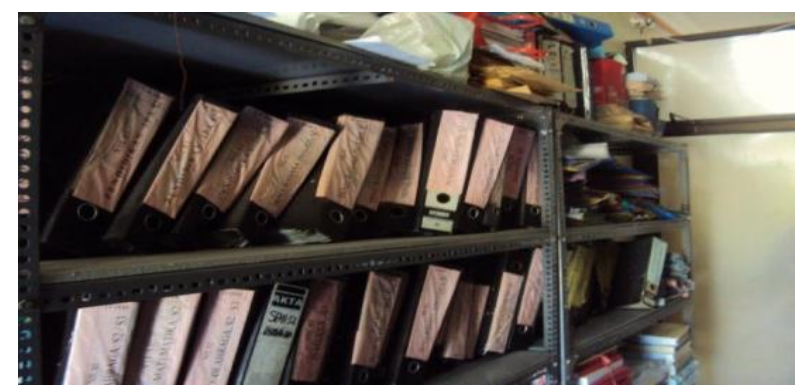

Gambar 2. Lemari Arsip Yang Belum Berstandar Kearsipan

PPs UNNES dalam anggaran tidak ada mata anggaran khusus untuk kegiatan penataan kearsipan. Perhatian pada kegiatan kearsipan masih minim. Pada tahun 2016 ada gugus dokumen dan kearsipan di PPs UNNES. Dalam tugasnya belum maksimal karena banyak faktor yang dihadapinya, terutama masalah pendanaan. Kendala-kendala dalam manajemen kearsipan tersebut di PPs UNNES menjadi bukti untuk pengabdi melakukan tindakan pengabdian kepada masyarakat di PPS UNNES. Ini sebagai bukti kelemahan PPs UNNES dalam mengelola kearsipan.

Konsep dasar mengenai arsip yang dikemukakan oleh Lundgren dan Carol A. (1989), arsip merupakan suatu bukti kejadian atau kegiatan yang terekam di daiam bentuk yang nyata atau bersifat tangible sehingga memungkinkan untuk diketemukan kembali. Dari pengertian ini terdapat beberapa unsur pemahaman tentang arsip. Pertama, arsip harus merupakan bukti (evidence) dari suatu kejadian, suatu arsip harus berisi data yang mempunyai makna secara sosial. Kedua, arsip harus disimpan di dalam bentuk yang nyata, hal ini didukung oleh pendapat Robek (1987) yang menyatakan bahwa arsip merupakan informasi yang terekam tanpa memperdulikan media perekamnya. Adapun media arsip secara umum terdiri dari kertas (paper), film dan magnetic (magnetic media) dan bahkan bentuk media yang harus dibaca dengan bantuan komputer. Dan ketiga, arsip harus dapat diketemukan kembali (retrievable) baik itu secara fisik maupun informasinya.

Berdasarkan konsep di atas, bahwa suatu arsip harus memiliki unsur-unsur sebagai berikut (a) arsip merupakan informasi yang terekam, (b) memiliki bentuk media yang dapat dilihat dan dibaca, diraba dan didengar; dan (c) arsip memiliki fungsi dan kegunaan di dalam rangka menunjang proses penyelenggaraan administrasi. Dari materinya menurut Undang-Undang Nomor 43 tahun 2009, bahwa arsip memuat empat unsur yang harus dimiliki, yaitu: benda, aktivitas, pelaku, dan konteks. Unsur pertama adalah benda dalam wujud fisik yang berupa rekaman kegiatan atau peristiwa, baik dalam bentuk yang konvensional (kertas) ataupun nonkonvensional (seperti film/video, kaset, media simpan elektronik dan berbagai macam variasi). Unsur kedua adalah aktivitas membuat dan menerima rekaman sebagai bentuk komunikasi atau hubungan antara pihak yang satu dengan yang lainnya, termasuk aktivitas kegiatan dari pengelolaan arsip.

Warkat adalah catatan tertulis, gambar atau rekaman yang memuat sesuatu hal atau peristiwa yang digunakan orang untuk sebagai pengingat (alat bantu ingatan). Warkat otomatis menjadi arsip begitu diproses untuk penyelesaian suatu kegiatan organisasi. Warkat sebagai bahan arsip mempunyai 4 kegunaan, yaitu guna informasi, guna yuridis; guna sejarah; dan guna ilmu pengetahuan (Martono, 1990).

Menurut Mulyono, Partono, dan Agung (2011) warkat dapat dibedakan menjadi 2 nilai guna sesuai dengan siapa yang memanfaatkan warkat tersebut. Secara otomatis warkat bernilai guna bagi organisasi yang menciptakan warkat tersebut atau pemilik warkat (nilai guna primer). Di samping itu warkat juga dapat dimanfaatkan oleh pihak lain di luar organisasi pencipta warkat yang bersangkutan (nilai guna sekunder). Sebagai contoh, laporan tahunan suatu organisasi dapat memiliki nilai guna primer karena bermanfaat untuk perkembangan yang akan datang bagi organisasi yang bersangkutan. Selain berguna bagi organisasi pencipta atau pemilik warkat, laporan itu dapat dimanfaatkan oleh organisasi lain sebagai bahan informasi dalam mengambil kebijakan untuk perkembangan organisasinya. Menurut Amsyah (1990) menata arsip dengan baik, arsip perlu dikelompokkan dalam 4 golongan.

Arsip yang timbul karena kegiatan suatu organisasi, berdasarkan golongan arsip perlu disimpan dalam jangka waktu tertentu. Ada arsip yang perlu disimpan sementara (sampai 1 tahun, sebagian lagi disimpan 1-5 tahun, yang lain 5-10 tahun, dan sebagian kecil dari jumlah arsip perlu disimpan secara abadi. Arsip yang disimpan pada bagian pengolah adalah arsip-arsip yang frekuensi penggunaannya cukup tinggi. Untuk arsip yang disimpan di unit kearsipan adalah arsip-arsip yang frekuensi penggunannya sangat rendah (Sugiarto dan Wahyono, 2005). Jadi, ada arsip yang dalam jangka waktu tertentu (1 tahun misalnya) sering dikeluarkan dari penyimpanan (dalam hal ini penyimpanan di unit pengolah). Sebaliknya ada arsip yang dalam jangka waktu 3 tahun sama seklai tidak pernah dikeluarkan untuk bahan informasi dalam kegiatan yang sedang dilasksanakan. Kedua macam arsip tersebut tetap mempunyai nilai dokumenter. 
Setiap organisasi dalam mencapai tujuannya dibutuhkan informasi yang akurat termasuk data lama (arsip) karena mengandung nilai yang penting bagi organisasi. Demikian juga tenaga kependidikan Pascasarjana UNNES harus mampu mengelola arsip dinamis yang ada di lembaganya sehingga apabila ada pihak yang membutuhkan suatu arsip akan mudah dalam penemuan kembali (finding).

Berdasarkan uraian di atas maka permasalahan yang dalam pengabdian kepada masyarakat ini adalah (1) Bagaimana cara mengelola arsip dalam upaya pelayanan prima bagi tenaga kependidikan Pascasarjana UNNES? (2) Apa dampak pengelolaan arsip dinamis bagi Pascasarjana UNNES?

Tujuan pengabdian kepada masyarakat ini adalah (1) untuk mengelola arsip dalam upaya pelayanan prima bagi tenaga kependidikan Pascasarjana UNNES. (2) Memberikan kontribusi pengelolaan arsip dinamis bagi Pascasarjana UNNES yang baik dan benar. Manfaat pengabdian kepada masyarakat ini adalah tenaga kependidikan Pascasarjana UNNES dalam mengelola arsip dinamis sesuai dengan kaidah manajemen kearsipan UNNES dan membekali bagi tenaga kependidikan untuk dapat menata arsip yang dikelolanya di unit kerjanya.

\section{BAHAN DAN METODE}

Bahan dalam pengabdian ini adalah buku agenda surat masuk dan keluar, dokumen arsip, kartu kendali, buku ekspenditur/ pengantar surat (masuk dan keluar), kartu pinjam arsip, pensil dan bolpen, dan kertas disposisi. Peralatannya meliputi lemari arsip. Selain itu, ada bahan seperti pedoman kearsipan dinamis UNNES yang didalamnya ada rangkaian dan cara pengelolaannya.

Untuk mengatasi permasalahan yang ada bagi tenaga kependidikan Pascasarjana UNNES maka perlu adanya penyampaian teori dan praktek manajemen arsip dinamis. Adapun pola yang di buat dalam kegiatan ini untuk dapat memecahkan permasalahan yaitu penyampaian materi, praktek arsip dinamis, dan mengevaluasi kegiatan. Tahapan pelatihan dalam kegiatan pengabdian kepada masyarakat dapat digambarkan sebagai berikut

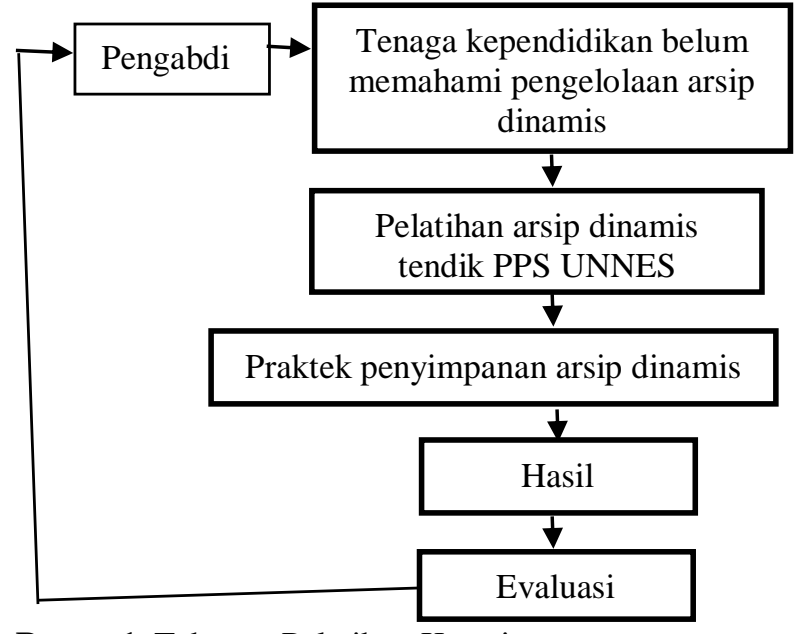

Bagan 1. Tahapan Pelatihan Kearsipan
Realisasi pemecahan masalah dilakukan dengan cara pemberian teori dan workshop pada tanggal 7 September 2016 bertempat di PPs UNNES di Aula dengan dihadiri semua tenaga kependidikan PPs UNNES. Sasaran kegiatan ini adalah tenaga kependidikan Pascasarjana UNNES. Kegiatan ini merupakan dalam rangka pelayanan prima bagi tenaga kependidikan. Alasan kegiatan pengabdian kepada masyarakat ini dilakukan tenaga kependidikan Pascasarjana karena tenaga kependidikan PPs UNNES ada beberapa yang belum memahami pengeolalan arsip dinamis. Kegiatan ini terkait dengan pelayanan prima yang dilakukan Pascasarjana UNNES dalam rangka UNNES yang good govermance.

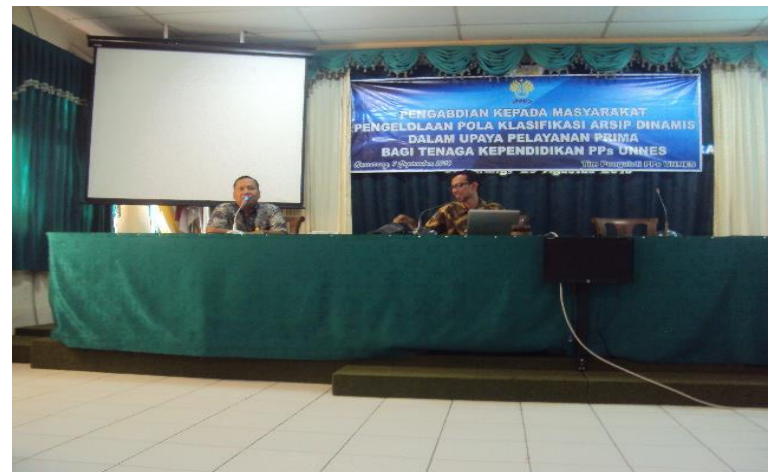

Gambar 2. Pengabdi Memaparkan Materi Kearsipan

\section{HASIL DAN PEMBAHASAN}

Hasil dari pengabdian ini adalah pengabdi memahami teori yang akan disampaikan oleh tim pengabdi. Peserta pelatihan memahami pengelolaan arsip aktif atau dinamis yang ada diunit kerjanya. Pengelolaan arsip aktif dimulai dari penciptaan arsip. Penciptaan arsip meliputi pembuatan, penerimaan, pencatatan, dan penyimpanan arsip. Urutan tahapan dalam pola klasifikasi arsip aktif di UNNES yaitu (1) Penjelasan materi dari modul yang akan dibagikan (2) Pembagian arsip berupa surat masuk dan keluar ke peserta pelatihan (3) Memperhatikan lembar disposisi. Diasumsikan surat tersebut diarsip. Setelah itu, surat dicatat ke buku agenda masuk - keluar (4) Mencatat arsip tersebut ke buku identifikasi arsip masuk - keluar (5) Mempola klasifikasikan arsip sesuai dengan pola klasifikasi UNNES (6) Memasukkan arsip ke dalam laci, guide, dan map ke filing cabinet (7) Mengecek arsip tersebut sesuai dengan pola klasifikasi yang telah ditentukan.

Urutan peminjaman arsip yaitu (1) Membagikan lembar pinjam arsip (2) Menjelaskan form isi lembar arsip pinjam arsip (3) Praktek peminjaman arsip. Arsip yang dipinjam, diambil kemudian kertas pinjam yang berwarna putih ditinggal (atau ada tanda bahwa arsip sedang dipinjam),

Urutan pengembalian arsip yaitu (1) Membagi form pengembalian arsip (2) Penjelasan form pengembalian arsip (3) Arsip yang dipinjam dikembalikan sesuai dengan pola klasifikasinya (4) Mengambil tanda bahwa arsip yang dipinjam sudah dikembalikan 
Aspek yang dievaluasi dalam kegiatan ini adalah keterampilan, ketelitian, kerapian, dan kecerdasan. Keterampilan adalah cekatan menempatkan (placing), penemuan kembali (finding), dan memilah golongan arsip. Ketelitian yang dimaksudkan adalah pada tingkat kecerdasan memaknai angka dan huruf. Kerapian adalah sikap pandang tentang keteraturan, keberesan, ketertiban, dan keapikan. Map, folder, guide (lembar petunjuk) dan laci ditata secara teratur, tertib, dan anak dipandang, karena berdampak pada kecepatan menyimpan dan menemukan arsip. Cerdas berarti tingkat pemahaman arsip sesuai dengan tugas dan pekerjaannya. Evaluasi dilakukan dengan penugasan berupa latihan soal earsip.

PPs UNNES adalah unit kerja di UNNES yang menyelenggarakan khusus pendidikan strata dua dan tiga, sehingga ia memiliki peran yang sangat vital dalam kemajuan UNNES. Oleh karenanya, perlu dokumen atau arsip yang dikelolanya harus ditata sebagai dasar dalam membuat kebijakan atau keputusan atas informasi yang tersaji dalam arsip tersebut.

UNNES telah memiliki pola klasifikasi, Jadwal Retensi Arsip (JRA), tata naskah surat dinas, pengelolaan arsip dinamis, dan pedoman lainnya mengenai kearsipan. Namun, itu semua perlu didukung oleh unit kerja, salah satunya PPs UNNES. Cara menata arsip di PPs UNNES salah satunya dengan membuat record center PPs UNNES. Namun, untuk mewujudkan record center bukan hal yang mudah, karena dibutuhkan komitmen yang kuat dari pimpinan dan sumber daya yang kompeten. The right man on the right place atau penempatan orang sesuai dengan tempatnya menjadi prinsip utama dalam penataan arsip. Jangan sampai penataan arsip dilakukan asal saja. Menata arsip memiliki kaidah dan pola tersendiri. Oleh karenanya perlu dirancang.

Adapun rancangannya ada beberapa tahap. Pertama, unit kerja (PPs UNNES) harus memiliki SOP mengenai pola klasifikasi kearsipan dan tata naskah dinas. SOP sebagai pedoman orang yang bekerja agar sesuai prosedur sehingga tujuan organisasi cepat tercapai. Ilustrasinya saat orang pekerja bangunan akan masuk ke gedung yang sedang dikerjakan, maka ia akan memakai helm, rompi warna cerah, sepatu, membawa peralatan kerja, dan bekal lainnya. Tujuannya ia memakai atribut seperti itu adalah agar ia selamat dan menghindari hal-hal yang tidak diinginkan.

Penata dokumen menuliskan surat masuk-keluar ke buku agenda, membuat kartu kendali, mengklasifikasikan, memberkas arsip, menyimpan arsip, memelihara arsip, mengamankan arsip, dan menyusutkan arsip. Setiap pekerjaan penata dokumen pasti memiliki langkah kerjanya agar ia selamat dan terhindar dari hal-hal yang tidak diinginkan seperti arsip hilang atau merasa sudah menerima arsip, padahal belum menerima arsip. Oleh karenanya, SOP kearsipan di PPs UNNES sangat dibutuhkan, sebagai acuan penata dokumen dalam bekerja.

Kedua, unit kerja memiliki sumber daya (penata dokumen) yang potensial dibidang administrasi. Hal ini sangat penting, karena menata arsip dibutuhkan profesionalitas, sehingga kita mengenal arsiparis, dimana ia memiliki tugas utama menata arsip. Kenyataan selama ini, ada rotasi pegawai pada penata dokumen atau tendik, namun UNNES masih terbatas dalam tenaga arsiparisnya, sehingga menyulitkan dalam penataan arsip. Oleh karenanya, cara yang harus ditempuh adalah menguatkan SOP dan memberikan pelatihan dan pendampingan dalam kearsipan.

Ketiga, menata arsip membutuhkan ruangan atau record center. Tujuannya adalah menyimpan arsip atau depo arsip dari masing-masing subunit atau prodi. Depo arsip ini menjadi pusat penyimpanan arsip PPs UNNES. Arsip yang aktif masih disimpan di subunit atau prodi, sedangkan arsip yang masa umurnya sudah habis dan masih berguna, serta memiliki nilai guna, maka disimpan di depo arsip. Untuk memindahkan arsip dari subunit kerja ke unit kerja atau record center atau depo arsip juga harus sesuai dengan prosedur, yaitu dengan mencatat arsip mulai dari judul arsip, tahun arsip, pola klasifikasi, jumlah arsip, bentuk arsip, dan retensi arsip.

Cara penyerahan arsip bukan berwujud berkasberkas yang dibendel tali rafiya atau berkas yang dimasukkan ke kardus, kemudian dikirim ke depo arsip. Sebelum dikirim ke depo arsip, dibuatkan berita serah terima arsip dari subunit kerja ke unit kerja. Jadi, bukan asal mengirim berkas ke record center.

Ketiga rancangan itulah yang dapat kita lakukan dalam menata arsip, khususnya membuat record center. Memang bukan hal mudah untuk menciptakan arsip yang rapi dan tertib, sehingga penemuan kembali (finding) arsip dapat cepat ditemukan. Semoga arsip PPs UNNES dapat tertata dengan rapi sesuai dengan kaidah manajemen kearsipan.

Model pengelolaan arsip dinamis di PPs UNNES saat ini adalah ditata oleh tenaga kependidikan yang ada di beberapa prodi. Ada yang dua prodi dikelola oleh satu orang tenaga kependidikan dan ada yang satu prodi dikelola oleh satu orang tenaga kependidikan. Ketentuan banyak orang yang mengatur atau mengelola dokumen ditiap prodi tergantung pada besar kecilnya prodi tersebut. Misal, prodi manajemen pendidikan, merupakan prodi yang banyak dalam mengelola dokumen, sehingga dibutuhkan tenaga kependidikan sebanyak satu orang yang mengelolanya. Sebaliknya, prodi pendidikan ekonomi, dalam mengelola dokumennya, dilakukan oleh tenaga kependidikan sebanyak satu orang, tetapi ia (tenaga kependidikan tersebut) mengelola dokumen prodi lain yaitu prodi evaluasi pendidikan. Arsip-arsip yang dikelola oleh tenaga kependidikan ditiap prodi memiliki masa simpan hingga lima tahun.

Asas penyimpanan arsip yang digunakan adalah gabungan sentralisasi - desentralisasi. Asas sentralisasi digunakan untuk menyimpan arsip-arsip yang bersifat kelembagaan PPs UNNES seperti kerjasama, surat ijin penelitian, surat keterangan mahasiswa, dan lainnya. Sedangkan asas desentralisasi digunakan untuk menyimpan arsip-arsip yang bersifat prodi.

Adapun pengkodean dalam PPs UNNES meliputi A (Pendidikan IPA), B (Pendidikan Bahasa 
Inggris), C (Pendidikan Seni), D (Pendidikan Olahraga), E (Manajemen Kepen-didikan), F (Pendidikan Dasar), G (Pengembangan Kurikulum), H (Program Studi Penelitian dan Evaluasi Pendidikan), I (Pendidikan Matematika), J (Pendidikan Bahasa Indonesia), dan K (Pendidikan IPS).

Laci 1 dari Kode berisi tentang SK pembimbing Thesis Dikdas S2, SK pembimbing thesis matematika, SK Pembimbing thesis IPS S2, SK pembimbing bahasa inggris S2, SK Pembimbing S3, SK Pembimbing BK S2, SK pembimbing IPA S2, SK Pembimbing S2, SK Pembimbing MP S2, SK pembimbing S2, SK pembimbing thesis KTP, SK Pembimbing thesis POR, SK Pembimbing Promotor Disertasi Pend. Bahasa Inggris, dan SK Pembimbing promotor disertasi MP. Laci 2 meliputi IND, KM, Bahasa, arsip undangan, arsip, permohonan ijin penelitian, ING, Ijin penelitian Indonesia, Seni dan Bahasa. Laci 3 meliputi ING Nilai ujian masuk S3, IND, CV Dosen, ING, Seni, dan Nilai.

Alur untuk menciptakan arsip dinamis sebagian besar berasal dari sumber diciptakannya arsip tersebut. Misal, ada mahasiswa yang akan membuat surat keterangan mahasiswa aktif, maka tenaga kependidikan di prodi membuatkan blangko atau form untuk kebutuhan tersebut. Kemudian diteruskan ketua prodi untuk ditanda tangani. Prodi menjadi "dapur" dalam menciptakan dokumen-dokumen yang bersifat keprodian. Setiap orang yang mengajukan suatu surat keterangan (baca: dokumen) harus memiliki kartu identitas warga PPs UNNES, misal Kartu Tanda Mahasiswa (KTM). Melalui gabungan kedua asa yaitu sentralisasi - desentralisasi mempermudah prodi dalam mengelompokkan arsip-arsipnya yang ada di prodi. Sedangkan untuk urusan kelembagaan, jelas arsipnya ada di pusat PPs UNNES.

Tenaga kependidikan berlatar belakang pendidikan yang bermacam-macam, hanya beberapa yang berlatar belakang administrasi perkantoran (sekretaris), dimana memahami mengenai pengelolaan dokumen atau kearsipan. Perbedaan inilah, menjadi salah satu hambatan dalam memberikan layanan prima berupa pembuatan dan peminjaman arsip. Hal ini terjadi, karena mereka tidak dibekali dengan ilmu kearsipan. Sehingga berdasarkan pengamatan penulis, ada prodi yang rapi dan sistematis dalam mengelola kearsipannya dikarenakan tenaga kependidikan berlatar belakang pendidikan administrasi perkantoran. Sebaliknya, ada prodi yang dalam pengelolaan arsipnya tidak rapi dan sistematis, dikarena-kan tenaga kependidikan yang mengelola arsip di prodi tersebut tidak berlatar belakang pendidikan administrasi perkantoran.

Keadaan tersebut, PPs UNNES memberikan workshop atau pelatihan kearsipan bagi tenaga kependidikan. Pelatihan tersebut dilakukan oleh gugus dokumen dan arsip. Gugus tersebut bertugas mengelola doku-men dan arsip yang ada di lembaga PPs, termasuk prodi-prodinya. Keberadaan gugus tersebut sangat penting terutama saat akreditasi.

Gugus tersebut salah satunya memberikan pelatihan kearsipan bagi tenaga kependidikan PPs UNNES. Tujuannya sederhana agar tenaga kependidikan dapat menyiapkan arsip yang baik dan benar, sehingga memberikan dampak pada pelayanan yang baik berupa pencarian dokumen dan arsip dalam waktu yang singkat, karena selama ini penataan arsip belum tertata, sehingga saat pencarian arsip dibutuhkan waktu yang lama.

Kendala-kendala saat penataan arsip dinamis yaitu kebijakan dan sumber daya. kebijakan kearsipan di PPs UNNES belum begitu terasa, karena belum ada pola klasifikasi yanag jelas ditiap prodi. Tenaga kependidikan yang mengelola arsip prodi tidak memiliki pedoman kearsipannya. Padahal UNNES sudah memiliki panduan dalam pengelolaan arsip dinamis, namun tidak semua tenaga kependidikan menggunakan pedoman tersebut. Kebijakan kearsipan PPs UNNES juga belum ada dalam pengelolaan arsip inaktif, statis, atau pemindahan arsip (akuisisi) arsip dari prodi ke lembaga PPs. Akuisisi arsip sangat penting karena ada arsip-arsip di prodi yang bernilai kesejarahan, namun disimpan di prodi. Seharusnya disimpan atau diakuisisi di pusat (lembaga PPs UNNES)

Sumber daya juga menjadi kendala dalam mengelola arsip dinamis yaitu pendanaan untuk program kearsipan. Kegiatan-kegiatan kearsipan masih belum menjadi prioritas bagi lembaga PPs UNNES. Beberapa pimpinan masih beranggapan, bahwa kegiatan kearsipan belum menarik perhatian-nya. Mereka masih berfokus pada reputasi akademik. Padahal, masalah kearsipan pun perlu diperhatikan.

Dampak dari kebijakan kearsipan yang masih belum mendapatkan perhatian adalah minimnya pendanaan dalam bidang kearsipan. Oleh karenanya, PPs UNNES dapat dikatakan masih minim dalam kebijakan dan pembiayaan kearsipan. Kegiatan kearsipan masuk dalam gugus dokumen dan arsip.

Kendala lainnya adalah minimnya sumber daya yang memahami manajemen kearsipan. Latar belakang pendidikan tenaga kependidikan yang tidak berlatar belakang administrasi perkantoran juga menjadi masalah tersendiri. Hal ini sebagaimana permasalahan di atas. Salah satu untuk mengatasi permasalahan ini adalah dengan mengadakan kegiatan workshop atau pelatihan melalui gugus dokumen dan arsip.

Selain kendala, kebijakan kearsipan dan sumber daya. Kendala lainnya adalah sarana dan prasarana yang minim. Tiap prodi diberi lemari dan filing cabinet untuk mengelola arsipnya. Belum ada semacam kertas petunjuk (baca: guide) atau buku agenda surat masukkeluar ataupun mobile file yang khusus menampung arsip di PPs UNNES. Jadi arsip PPs UNNES ada pada lemari-lemari yang ada di prodi-prodi dan lembaga pusat. Hal ini terjadi, karena masih minimnya alokasi anggaran untuk kearsipan.

Beberapa kendala di atas tidak menjadi faktor untuk memberikan pelayanan kearsipan di PPs UNNES. Tiap-tiap tenaga kependidikan tetap mengelola kearsipan yang ada di prodinya. Demikian juga pimpinan tetap memikirkan langkah-langkah alternatif kebijakan tentang kearsipan di lembaganya. Hal ini dilakukan karena mereka memahami bahwa arsip adalah sumber informasi yang autentik, sah, dan 
realibel. Apa pun keadaan arsip harus disimpan, dirawat, dan dijaga keamanannya.

Arsip Dinamis yang ada di PPs UNNES meliputi pengarsipan tata naskah dinas (masuk dan keluar) serta dokumen-dokumen yang ada di subunit kerja. Naskah dinas masuk meliputi tahap penerimaan, pencatatan, pendistribusian dan pengendalian. Penerimaan naskah dinas dilakukan dengan cara memeriksa kelengkapan naskah dinas, penanda-tanganan bukti penerimaan, penyortiran, pembukaan naskah dinas kecuali naskah dinas yang berkualifikasi rahasia dan pribadi, pemberian lembar disposisi pada setiap naskah dinas masuk.

Pencatatan naskah dinas dilakukan dengan cara mencatat data identitas naskah dinas yang meliputi: asal naskah dinas, tanggal, nomor, klasifikasi (rahasia, penting, amat segera, dan segera), isi ringkas dan tujuan naskah dinas. Sarana pencatatan naskah dinas meliputi lembar disposisi, lembar pengantar dan atau buku agenda.

Pendistribusian naskah dinas dilakukan dengan cara mencatat pada lembar distribusi atau ekspedisi naskah dinas kemudian mendistri-busikan naskah dinas sesuai dengan unit pengolah/tujuan naskah dinas.

Pengendalian naskah dinas dilakukan dengan cara memeriksa aliran naskah dinas dari unit pengolah yang satu ke pengolah lainnya sampai dengan proses penyelesaian isi naskah dinas sehingga menjadi berkas kerja yang lengkap.

Naskah dinas masuk dilakukan secara terpusat (azas satu pintu) yaitu melalui suatu satuan kerja yang menangani penerimaan dan pengirimannya dengan maksud agar semua dokumen tercatat dan dapat diarahkan/dikendalikan secara sentral. Pengarsipan naskah dinas masuk dikelompokan berdasarkan kode klasifikasi arsip yang dapat dilihat dari perihal surat.

Naskah dinas keluar meliputi pembuatan konsep, pengetikan, penandatanganan, penomoran, pencatatan dan pengiriman. Ketentuan pembuatan konsep, pengetikan, penandatanganan, penomoran naskah dinas keluar dibuat sesuai dengan kaidah tata naskah dinas yang berlaku.

Pencatatan naskah dinas dilakukan dengan cara mencatat data identitas naskah dinas sekurangkurangnya meliputi tujuan naskah dinas, nomor, tanggal, serta isi ringkas naskah dinas pada sarana pencatatan naskah dinas. Pengiriman naskah dinas dilakukan melalui pos, menggunakan facsimile, kurir/caraka atau orang lain.

Hal-hal penting dalam pengelolaan naskah dinas adalah (1) Pengurusan naskah dinas masuk dan naskah dinas keluar dapat menggunakan buku, kartu, atau perangkat elektronik. (2) Buku dan kartu meliputi sekurang-kurangnya

buku agenda naskah dinas, lembar pengantar naskah dinas, lembar disposisi, buku ekspidisi. (3) Penerimaan naskah dinas harus disusun dan dikelompokkan sesuai nama dan alamat yang tercantum pada naskah dinas. (4) Pengelompokan untuk menentukan naskah dinas dan naskah pribadi. (5) Meneliti kebenaran alamat yang tercantum pada naskah dinas. (6) Naskah dinas yang bersifat rahasia dan pribadi

disampaikan dalam keadaan tertutup. (7) Lampiran naskah dinas tetap menyatu, jika lampiran tidak ada atau hilang berilah catatan pada kolom yang tersedia pada kartu lembar disposisi. (8) Surat yang dibuat dan ditandatangani oleh rektor atau pembantu rektor. Kode surat dibuat sesuai dengan tata naskah dinas yang berlaku.

Dalam pengarsipannya surat di kelompokkan sesuai dengan kode surat. Flowchard pengelolaan arsip dinamis UNNES sebagaimana terlihat gambar berikut:

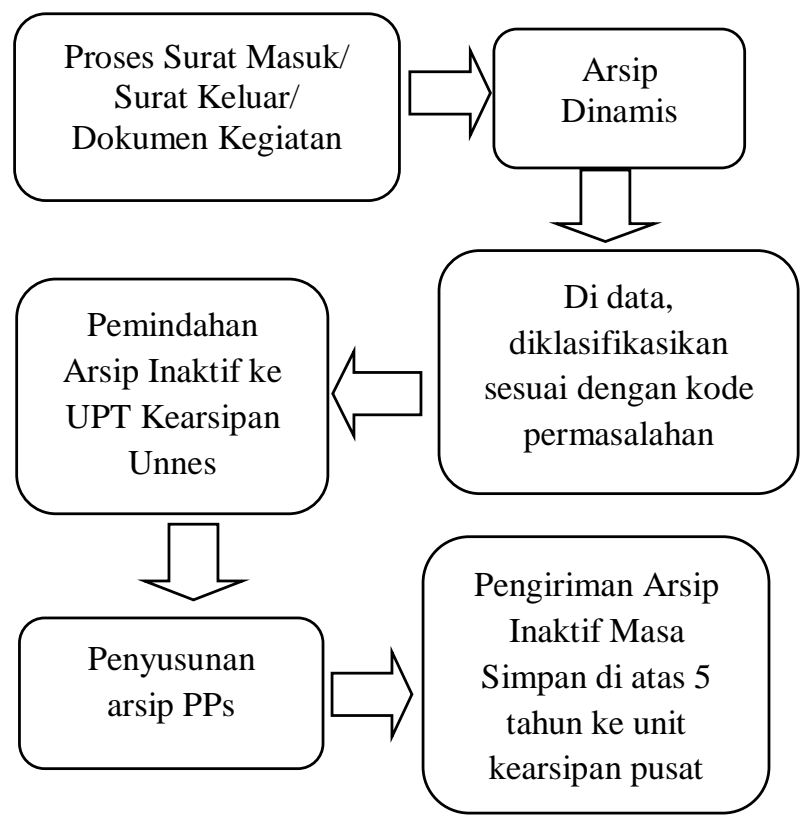

Bagan 2. Flowchard Pengelolaan Arsip Dinamis

Flowchard pengelolaan arsip dinamis UNNES meliputi proses surat masuk/ keluar/ dokumen kegiatan, arsip dinamis, didata. diklasifikasikan sesuai dengan kode permasalahan, pemindahan Arsip Inaktif ke UPT Kearsipan Unnes, penyusunan arsip di Fakultas Ekonomi Unnes, dan pengiriman arsip inaktif masa simpan di atas lima tahun ke unit kearsipan pusan Unnes (UPT Kearsipan Unnes).

Kegiatan pengelolaan arsip di PPs UNNES meliputi (1) Pemberkasan yaitu pendataan arsip, penilaian arsip, pemusnahan arsip, penataan arsip dalam folder, penataan arsip dalam boks, pelabelan boks. (2) Penyimpanan, yaitu penempatan boks dalam almari arsip dan penemuan kembali. (3) Perawatan, yaitu pembersihan arsip dari kotoran, fumigasi/ penyemprotan anti serangga/ jamur, dan alih media arsip. (4) Penyelamatan/ pengamanan yaitu penyerahan ke pusat arsip (UPT Kearsipan UNNES) dan pembuatan berita acara serah terima arsip. (5) Penggunaan meliputi peminjaman arsip.

Evaluasi kegiatan kearsipan di PPs UNNES adalah ada beberapa tenaga kependidikan masih beranggapan bahwa arsip, bukan hal yang penting sehingga berpengaruh dalam pengelolaan kearsipan. Dalam pelaksanaan penataan arsip sudah ada SOP dari 
UPT Kearsipan UNNES, namun belum dilaksanakan. Selain itu, PPs UNNES belum ada pedoman kearsipan sehingga berdampak pada penataan di lapangan.

Tantangan dalam pelayanan prima bidang kearsipan adalah tenaga administrasi yang terampil dalam bidang kearsipan yang masih minim, karena diantara mereka (tenaga administrasi) masih menyelekan keberadaan arsip. Solusi dalam permasalahan ini adalah adanya pelatihan yang intensif dan pendampingan dari pusat (UPT Kearsipan) yang berkelanjutan di PPs UNNES hingga pada subunit kerja.

\section{SIMPULAN}

Simpulan dalam pengabdian ini adalah peserta memahami penataan arsip dinamis yang ada di PPs UNNES dan memberikan dampak dalam memberikan pelayanan prima bagi tenaga kependidikan PPs UNNES. Tenaga kependidikan mampu mempraktekkan pengelolaan kearsipan dibuktikan dengan mereka mampu memproses perjalanan arsip mulai dari pemberkasan, penyimpanan, perawatan, penyelamatan, dan penggunaan (pengembalian) arsip. Tenaga kependidikan juga memahami cara memberkas dan mempola klasifikasi arsip dinamis, yang awalnya mereka belum memahami. Hasil angket menunjukkan bahwa peserta pelatihan $93 \%$ memahami materi secara teori dan 95\% mampu mempraktekkan pengelolaan arsip dinamis. Model pelatihan ini menjadi model dalam pembinaan kearsipan di UNNES, karena peserta praktik secara langsung dengan bahan-bahan yang telah dipersiapkan. Dampak setelah pelatihan ini dari angket yang mereka isikan adalah mereka mampu melayani, terutama dalam pencarian arsip kembali (finding) dengan cepat. Maksimal penemuan arsip kembali adalah 3 menit.

Saran dalam pengabdian ini adalah peserta pelatihan harus terampil dalam penataan arsip mulai dari pemberkasan, pencatatan, penyimpanan, dan pengembalian arsip dengan mempraktekkan secara langsung di unit kerjanya. Selain itu, perlu didukung sarana dan prasarana dalam mendukung penataan arsip, serta pembiayaan program kearsipan yang minim. Pelatihan ini juga direncanakan secara rutin tiap tahun dengan alokasi anggaran dari PPs UNNES dan mendapat pendampingan dari kearsipan universitas (UPT Kearsipan UNNES) dalam rangka pembinaan kearsipan Universitas. PPs UNNES akan mengoptimalkan gugus dokumen dan kearsipan dalam peran dan fungsinya untuk mengelola kearsipan dan PPs UNNES dan UPT Kearsipan akan merencanakan pengiriman diklat/ workshop kearsipan secara periodik ke ANRI agar tenaga kependidikan lebih terampil dan profesional dalam pengelolaan kearsipan.

\section{DAFTAR PUSTAKA}

Amsyah, Z. 1990. Manajemen Kearsipan. Jakarta. Penerbit : PT Gramedia.
Lundgren dan Carol A. Lundgren. 1989. Records Management In The Computer Age. USA: Boston, Mass. : PWS-KENT Pub. Co., 1989.

Martono, E, 1990. Kearsipan (Record Manajemen dan Filing dalam Praktek Perkantoran Modern. Jakarta. Penerbit: Karya Utama.

Mulyono, Partono, dan Agung K. 2011. Manajemen Kearsipan. Semarang : Unnes Press.

Pedoman Kearsipan UNNES. 2013. Semarang: BUHK UNNES

Sugiarto, A. dan Wahyono, T. 2005. Manajemen Kearsipan Modern dari Konvensional ke Basis Komputer. Yogyakarta: Penerbit Gava Media.

Robek. 1987. Information And Records Management. USA: Mission Hills, Calif. Glencoe Publishing Company.

Undang-Undang Nomor 43 Tahun 2009 tentang Kearsipan. 